\title{
Effects of pretreatment on the sequential phosphorus fractionation of anaerobic sediment
}

\author{
Lei ZHANG, ${ }^{1 *}$ Qianjiahua LIAO,${ }^{2}$ Chao ZENG, ${ }^{2}$ Qiongli MO,${ }^{2}$ Chengxin FAN ${ }^{1}$ \\ ${ }^{1}$ State Key Laboratory of Lake Science and Environment, Nanjing Institute of Geography and Limnology, Chinese Academy of Sciences, \\ Nanjing 210008, China; ${ }^{2}$ Department of Environmental Science, China Pharmaceutical University, Nanjing 211198, China \\ *Corresponding author: leizhang@niglas.ac.cn
}

\begin{abstract}
Phosphorus $(P)$ fractionation is critical to understand P cycling in sediment and across the sediment-water interface. To examine the effect of pretreatment on the P fractionation of anaerobic sediment, anaerobic sediment samples were treated by oven-drying, airdrying, and freeze-drying, and a fresh sediment sample was used as a control treatment. A five-step sequential extraction procedure was applied, and six $P$ fractions were examined. The results indicated that $P_{\mathrm{NaCl}}(\mathrm{P}$ extracted by $\mathrm{NaCl}), \mathrm{P}_{\mathrm{BD}}\left(\mathrm{P}_{\text {extracted by } \mathrm{Na}} \mathrm{S}_{2} \mathrm{O}_{4}\right.$ and $\left.\mathrm{NaHCO}_{3}\right), P_{\mathrm{NaOH}}(P$ extracted by $\mathrm{NaOH})$, and organic $P$ were significantly influenced by pretreatment, whereas $P_{\mathrm{HCl}}(P$ extracted by $\mathrm{HCl}$ ) and residual $P$ were not significantly affected by pretreatment. Compared to fresh sediment, drying treatments decreased $P_{\text {NaCl}}$, $P_{\mathrm{NaOH}}$, and organic $P$ but increased $P_{B D}$. Among the three drying methods, oven-drying resulted in the greatest change in $P$ fractionation; the effects of air-drying and freeze-drying were similar to each other. The total extracted $P$ were similar among the four pretreatment methods. For the measurement of accurate P fractions, fresh sediment is the best option.
\end{abstract}

Key words: pretreatment, phosphorus fractionation, sequential extraction, sediment.

Received: September 2013. Accepted: December 2013.

\section{INTRODUCTION}

Phosphorus (P) is a key element for all life, and it plays a vital important role in global ecosystem health and element cycles (Elser, 2012; Mackey and Paytan, 2009). The massive use of $\mathrm{P}$ by humans is reducing this scarce resource; at the same time, a large amount of $P$ enters into rivers, lakes, and oceans, where it causes costly eutrophication (Elser, 2012; Carpenter, 2008). In view of the global P cycle, sediment acts as a P sink (Mackey and Paytan, 2009; Sharpley et al., 2013). P in sediment can be divided into organic $\mathrm{P}$ and inorganic $\mathrm{P}$ (Ruban et al., 2001). Inorganic $P$ is often bound to iron, aluminum, and calcium compounds or to clay minerals (Lukkari et al., 2007a). In sediment, P transforms from organic to inorganic form or from particulate to soluble form and it can be released from sediment to overlying water, acting as an internal source, through molecular diffusion, advection, re-suspension, and so on (Paytan and McLaughlin, 2007; Søndergaard et al., 2001; Spears et al., 2007). Therefore, understanding P transformation and transportation in sediment or across the sediment-water interface, is essential for mapping the global $\mathrm{P}$ cycle and controlling eutrophication. Moreover, knowing the bound forms of $\mathrm{P}$ in sediment is critical to understanding $\mathrm{P}$ transformation and transportation (Wang et al., 2013).

Several chemical extraction procedures and modifications have been developed to identify the binding forms of
P in sediment; Ruban et al. (1999), Golterman (2004), and Wang et al. (2013) reviewed and commented on these methods in detail. The sequential extraction procedure by Jensen and Thamdrup (1993) that modified from Psenner et al. (1988) is popular. This procedure provides more detailed information on $\mathrm{P}$ forms of interest in risk assessment of internal $\mathrm{P}$ loading and gives more reliable estimates on the bioavailability of sediment P (Lukkari et al., 2007a).

Phosphorus fractionation is a complex and time-consuming process; therefore, the full determination of $\mathrm{P}$ fractionation for many sediment samples immediately after they have been sampled is difficult or impossible. In addition, storage influences the $\mathrm{P}$ fractionation of fresh sediments (Lukkari et al., 2007b). Hence, sediment samples earmarked for $\mathrm{P}$ fractionation are pretreated by air-drying, oven-drying, or freeze-drying (Zhong et al., 2008; Sun et al., 2009; Gikuma-Njuru et al., 2010). Pretreatment is undoubtedly advantageous for sample preservation. However, sediment samples are exposed to oxygen during pretreatment, and they are usually anaerobic because only the surficial sediment (usually several millimeters to centimeters) is aerobic. The storage of anaerobic sediment in aerobic condition has been verified to change $P$ fractionation results, so does the storage of aerobic sediment in anaerobic condition (Psenner and Pucsko, 1988; Lukkari et al., 2007b). Golterman (1996) stated that freezing and drying changed the fractionation results. Drying and desiccation have been found to increase or decrease $\mathrm{P}$ bound to ferric 
oxyhydroxides (Fabre, 1992; De Groot and Fabre, 1993; Kerr et al., 2010). In addition, drying decreases or has no influence on calcium bound P (De Groot and Fabre, 1993; Kerr et al., 2010). Goedkoop and Pettersson (2000) demonstrated that freeze-drying resulted in higher estimates for loosely adsorbed $\mathrm{P}$, whereas $\mathrm{P}$ extracted by $\mathrm{NaOH}$ solution was decreased. Drying accelerates the mineralization of acid soluble organic $\mathrm{P}$ and decreases organic $\mathrm{P}$ in sediment (De Groot and Fabre, 1993; Kerr et al., 2010). The present study was designed specifically to test the hypothesis that pretreatment would influence $\mathrm{P}$ fractionation of anaerobic sediment. In the study, the Jensen and Thamdrup extraction procedure was applied, and effects of different pretreatments on sediment $P$ fractionation were compared.

\section{METHODS}

\section{Field sampling}

The sediment used in this study was collected from the western district $\left(31^{\circ} 18^{\prime} 19.1^{\prime \prime} \mathrm{N}, 119^{\circ} 55^{\prime} 58.2^{\prime}\right.$ ' E) in Lake Taihu, China. This district is eutrophic, and the oxygen penetration depth in the sediment is only several millimeters (Zhang et al., 2010). A sediment core was sampled with overlying water using a gravity core sampler $(11 \mathrm{~cm}$ internal diameter, $50 \mathrm{~cm}$ long; Rigo, Saitama, Japan). The core surface was yellow-brown with a depth of about $3 \mathrm{~mm}$, which indicated this section was aerobic. The deeper part of the core was dark, which indicated that it was anaerobic. The temperature of overlying water in the core was $11^{\circ} \mathrm{C}$. The core was closed with rubber stoppers at both ends and transported to the laboratory immediately.

\section{Pretreatment}

In the laboratory, the sediment core was sectioned in an anaerobic glove box (JMS-2, Nanjing Jiumen Automation Technology Co., Ltd, Nanjing, China), and sediment at the depth of $2-5 \mathrm{~cm}$ was used as the sample for sediment fractionation. The sample was well-homogenized by a hand-held eggbeater and was then divided into five portions. Two of the portions were separately transferred to $50 \mathrm{~mL}$ polypropylene centrifuge tubes (Nalgene, Rochester, NY, USA); another two portions were separately transferred to glass Petri dishes. All of the described operations were completed in the glove box. For the two centrifuge tubes filled with sediment, one (fresh sample) was immediately placed into a vacuum bag, evacuated to a pressure of less than $0.06 \mathrm{MPa}$, wrapped in aluminum foil (to shield the sample from light), and stored at $4^{\circ} \mathrm{C}$. The other centrifuge tube (freeze-dried sample) was immediately transferred to a $-20^{\circ} \mathrm{C}$ refrigerator; when the sediment was fully frozen, it was placed into a vacuum freeze dryer (FD-1A, Boyikang Laboratory Instruments Co., Ltd., Beijing, China) and then dried. For the two sediment pools in Petri dishes, one (oven-dried sample) was dried at $60^{\circ} \mathrm{C}$ in an oven $(9240 \mathrm{AD}$, Senxin, Shanghai, China) to a constant weight; the other (air-dried sample) was air dried to a constant weight at room temperature $\left(15-25^{\circ} \mathrm{C}\right)$. All drying pretreatments were conducted in air. All dried sediment samples were ground and sieved through $105 \mu \mathrm{m}$ mesh. The fifth sediment sample portion was used for analysis of sediment characteristics.

\section{Analyses of sediment characteristics}

About $10 \mathrm{~g}$ of the fifth portion of sediment was used for particle size analysis, which was measured using a laser size analyzer (Mastersizer 2000, Malvern Instruments Ltd., Malvern, UK). About $15 \mathrm{~g}$ sediment sample was oven-dried to a constant weight, as described above, in three replicates to determine the water content (\%). The dried sediment was subsequently ground and passed through a $105 \mu \mathrm{m}$ mesh. Loss on ignition (LOI, \%) of the sediment was calculated on the basis of the weight loss before and after calcination at $550^{\circ} \mathrm{C}$ for $5 \mathrm{~h}$. Nitrogen $(\mathrm{N})$ in the sediment was examined with a UV-VIS spectrophotometer (Shimadzu UV-2550, Japan) after the sample was digested in alkaline potassium persulfate (Chinese EPA, 2002). The content of $P$, iron (Fe), manganese (Mn), aluminum ( $\mathrm{Al})$, and calcium $(\mathrm{Ca})$ in the sediment was analyzed by inductively coupled plasma atomic emission spectrometry (ICP-AES, PerkinElmer DV4300, USA) after the sample was digested in acid. Phosphorus examined by ICP was identified as $\mathrm{P}_{\mathrm{ICP}}$ to distinguish it from $\mathrm{P}$ extracted in the successive extraction procedure.

\section{Phosphorus fractionation procedure}

Phosphorus fractionation was carried out on the fourth day after sediment sectioning. The experimental procedure is summarized in Tab. 1 and it is based on the methods of Jensen and Thamdrup (1993) and Lukkari et al. (2007a). P fractions of wet anaerobic sediment are not influenced by the short time store in oxygen-free environment (Lukkari et al., 2007b). The wet sediment was only preserved for 4 days in oxygen-free environment in our study. So the wet sample was treated as fresh sediment and represents the initial state of the sediment. For dried sediment samples, $0.25 \mathrm{~g}$ was weighed with six replicates from each pretreatment. For the fresh treatment, the wet weight corresponding to $0.25 \mathrm{~g}$ dry weight was calculated on the basis of sediment water content. The fresh sediment was also weighed with six replicates.

Samples were extracted with $0.46 \mathrm{~mol} \mathrm{~L}^{-1} \mathrm{NaCl}$ for $1 \mathrm{~h}$ in step 1. The samples were then centrifuged at $3000 \mathrm{rpm}$ for $15 \mathrm{~min}$, and the supernatant was collected. The sediment samples were subsequently rinsed once with $0.46 \mathrm{~mol} \mathrm{~L}^{-1}$ $\mathrm{NaCl}$ for $15 \mathrm{~min}$. In step 2, the sediment was extracted with $0.11 \mathrm{~mol} \mathrm{~L}^{-1} \mathrm{NaBD}\left(0.11 \mathrm{~mol} \mathrm{~L}^{-1} \mathrm{Na}_{2} \mathrm{~S}_{2} \mathrm{O}_{4}\right.$ in $0.11 \mathrm{~mol} \mathrm{~L}^{-1}$ $\mathrm{NaHCO}_{3}, \mathrm{pH}=7.0$ ) for $1 \mathrm{~h}$ and was sequentially rinsed with 
$0.11 \mathrm{~mol} \mathrm{~L}^{-1} \mathrm{NaBD}$ and $0.46 \mathrm{~mol} \mathrm{~L}^{-1} \mathrm{NaCl}$ for 15 min each. In step 3, $0.1 \mathrm{~mol} \mathrm{~L}^{-1} \mathrm{NaOH}$ was applied for $18 \mathrm{~h}$; this procedure was followed by a single $0.1 \mathrm{~mol} \mathrm{~L}^{-1} \mathrm{NaOH}$ rinse and a single $0.46 \mathrm{~mol} \mathrm{~L}^{-1} \mathrm{NaCl}$ rinse. In step 4 , the sediment was extracted with $0.5 \mathrm{~mol} \mathrm{~L}^{-1} \mathrm{HCl}$ for $1 \mathrm{~h}$, followed by a $15 \mathrm{~min}$ $0.46 \mathrm{~mol} \mathrm{~L}^{-1} \mathrm{NaCl}$ rinse. After step 4 , the sediment residue in the centrifuge tube was transferred carefully to a crucible, dried at $105^{\circ} \mathrm{C}$, and then calcined at $550^{\circ} \mathrm{C}$ for $2 \mathrm{~h}$. In step 5 , the calcined sediment residue was extracted with $1 \mathrm{~mol} \mathrm{~L}^{-1}$ $\mathrm{HCl}$ for $16 \mathrm{~h}$ to determine the residual $\mathrm{P}$. The volume of the extract and rinse solution was $25 \mathrm{ml}$ each time. The first two steps were conducted under a nitrogen atmosphere.

The extract and rinse solutions from a given step were combined into one extract. All extracts were filtered through $0.45-\mu \mathrm{m}$ cellulose acetate membrane filters. Extracts from the first and third steps were acidified to $\mathrm{pH}=2$ with sulfuric acid. NaBD extracts were bubbled with compressed air in a fume hood to remove dithionite, which decomposes to thiosulfate and hydrogen sulfite ions (Lukkari et al., 2007a); the $\mathrm{pH}$ was then adjusted to 2 . The concentration of $\mathrm{P}$ in the extracts was measured using the molybdenum blue method (Murphy and Riley, 1962). The total P in the $\mathrm{NaOH}$ extract was examined after the sample was digested by potassium persulfate; the difference between the total $\mathrm{P}$ and the directly examined $\mathrm{P}$ in $\mathrm{NaOH}$ solution $\left(\mathrm{P}_{\mathrm{NaOH}}\right)$ was identified as organic $\mathrm{P}\left(\mathrm{P}_{\mathrm{Org}}\right)$. All centrifuge tubes (Nalgene, USA) used in the experiment were soaked in $1 \% \mathrm{HCl}$, rinsed with deionized water, and then air dried. Reagents used in the experiments were analytical reagent grade. The results obtained for the sediment $\mathrm{P}$ fractions were expressed as dry weight (DW). In addition, all P fractions were the actual calculated data and not normalized considering $\mathrm{P}_{\mathrm{ICP}}$ of the sediment. Total extracted $\mathrm{P}\left(\mathrm{P}_{\text {Extr }}\right)$ is the sum of $\mathrm{P}_{\mathrm{NaCl}}, \mathrm{P}_{\mathrm{BD}}, \mathrm{P}_{\mathrm{NaOH}}, \mathrm{P}_{\mathrm{Org}}, \mathrm{P}_{\mathrm{HCl}}$, and $\mathrm{P}_{\mathrm{Res}}$.

\section{Statistical analysis}

For each $\mathrm{P}$ fraction, the data were checked for normal distribution and evenness firstly. One-way analysis of variance (ANOVA) was employed to test the difference among four treatments (fresh, freeze-drying, air-drying, and oven-drying). If a significant difference $(\mathrm{P}<0.05)$ was detected, Tukey's post-hoc test was then used to determine the difference between the two treatments. The statistical analysis was performed using the SPSS software package (SPSS 13.0, USA).

\section{RESULTS}

The sediment was composed of $12.5 \%$ clay, $80.6 \%$ silt, and $6.8 \%$ sand. The water content and LOI were $31.0 \%$ and $2.4 \%$, respectively. Total nitrogen accounted for $1178 \mathrm{mg}$ $\mathrm{kg}^{-1} \mathrm{DW}$, and $\mathrm{P}_{\mathrm{ICP}}$ accounted for $692 \mathrm{mg} \mathrm{kg}^{-1} \mathrm{DW}$. Total iron, aluminum, and calcium represented 22, 51, and 6.5 $\mathrm{mg} \mathrm{g}^{-1} \mathrm{DW}$, respectively, and total manganese represented $635 \mathrm{mg} \mathrm{kg}^{-1}$ DW (Tab. 2).

$\mathrm{P}_{\mathrm{NaCl}}$ was significantly influenced by pretreatment (Fig. 1, Tab. 3). The $\mathrm{P}_{\mathrm{NaCl}}$ in oven-dried sediment $\left(6.22 \pm 0.42 \mathrm{mg} \mathrm{kg}^{-1}\right)$ was significantly smaller than that of the other three treatments. The highest $\mathrm{P}_{\mathrm{NaCl}}(12.9 \pm 0.75 \mathrm{mg}$ $\mathrm{kg}^{-1}$ ) was observed in fresh sediment, and it was significantly higher than that in the other three treatments. The $\mathrm{P}_{\mathrm{NaCl}}$ in air-dried $\left(9.59 \pm 0.33 \mathrm{mg} \mathrm{kg}^{-1}\right)$ and freeze-dried $\left(8.77 \pm 0.44 \mathrm{mg} \mathrm{kg}^{-1}\right)$ sediments were similar. Pretreatment also significantly affected $\mathrm{P}_{\mathrm{BD}}$ (Fig. 1, Tab. 3). The highest $\mathrm{P}_{\mathrm{BD}}\left(270 \pm 19 \mathrm{mg} \mathrm{kg}^{-1}\right)$ appeared in the oven-dried sediment, whereas the lowest $\left(216 \pm 4.7 \mathrm{mg} \mathrm{kg}^{-1}\right)$ was observed in the fresh sediment. The results obtained with the oven-drying treatment were significantly different from those obtained using the other three treatments, and the results obtained with the fresh treatment was significantly different from those obtained using the freeze-drying treatment $(238 \pm 13$ $\mathrm{mg} \mathrm{kg}^{-1}$ ). In addition, the results for the freeze-dried and the air-dried $\left(223 \pm 4.6 \mathrm{mg} \mathrm{kg}^{-1}\right)$ samples were similar.

A significant difference was detected among the $\mathrm{P}_{\mathrm{NaOH}}$ values for the four treatments (Fig. 1, Tab. 3). Oven-drying significantly decreased the $\mathrm{P}_{\mathrm{NaOH}}\left(86.5 \pm 8.8 \mathrm{mg} \mathrm{kg}^{-1}\right)$ compared with the other three treatments. The fresh sediment

Tab. 1. Sequential phosphorus fractionation procedure.

\begin{tabular}{|c|c|c|c|}
\hline Step & Extract & Extract time $(\mathrm{h})$ & P fraction \\
\hline 1 & $0.46 \mathrm{~mol} \mathrm{~L}^{-1} \mathrm{NaCl}$ & 1 & Loosely adsorbed $\mathrm{P}$ and pore water $\mathrm{P}, \mathrm{P}_{\mathrm{NaCl}}$ \\
\hline 2 & $0.11 \mathrm{~mol} \mathrm{~L}^{-1} \mathrm{NaBD}\left(\mathrm{Na}_{2} \mathrm{~S}_{2} \mathrm{O}_{4}+\mathrm{NaHCO}_{3}\right), \mathrm{pH}=7.0$ & 1 & Redox sensitive $\mathrm{P}$, bound to reducible $\mathrm{Fe}$ and $\mathrm{Mn}$ oxides, $\mathrm{P}_{\mathrm{BD}}$ \\
\hline 3 & $0.1 \mathrm{~mol} \mathrm{~L}^{-1} \mathrm{NaOH}$ & 18 & $\begin{array}{l}\mathrm{P} \text { bound to } \mathrm{Al} \text { oxides, non-reducible } \mathrm{Fe} \text { oxides, and organic } \mathrm{P} \text {; } \\
\text { directly measured } \mathrm{P} \text { is called } \mathrm{P}_{\mathrm{NaOH}} \text {; the difference between total } \mathrm{P} \\
\text { after digestion and } \mathrm{P}_{\mathrm{NaOH}} \text { is organic } \mathrm{P} \text {, or } \mathrm{P}_{\mathrm{Org}}\end{array}$ \\
\hline 4 & $0.5 \mathrm{~mol} \mathrm{~L}^{-1} \mathrm{HCl}$ & 1 & $\begin{array}{l}\text { Apatite and other inorganic } \mathrm{P} \text {, named } \mathrm{P}_{\mathrm{HCl}} \\
\text { The residue was dried and calcined at } 550^{\circ} \mathrm{C} \text { for } 2 \mathrm{~h}\end{array}$ \\
\hline 5 & $1 \mathrm{~mol} \mathrm{~L}^{-1} \mathrm{HCl}$ & 16 & Residual $\mathrm{P}, \mathrm{P}_{\mathrm{Res}}$ \\
\hline
\end{tabular}

P, phosphorus. 
contained the highest $\mathrm{P}_{\mathrm{NaOH}}\left(121 \pm 6.0 \mathrm{mg} \mathrm{kg}^{-1}\right)$, which was significantly higher than the content in the oven-dried and air-dried $\left(106 \pm 3.6 \mathrm{mg} \mathrm{kg}^{-1}\right)$ sediments. The $\mathrm{P}_{\mathrm{NaOH}}$ in the freeze-dried $\left(115 \pm 4.6 \mathrm{mg} \mathrm{kg}^{-1}\right)$ and air-dried samples were similar. In addition, $\mathrm{P}_{\text {Org }}$ was significantly influenced by pretreatment (Fig. 1, Tab. 3). However, a significant differ-

Tab. 2. Main features of the sediment used for phosphorus fractionation $(\mathrm{n}=3)$.

\begin{tabular}{lc}
\hline Sediment properties & Mean \pm SD \\
\hline Particle size - clay $(0.02-4 \mu \mathrm{m}, \%)$ & $12.5 \pm 0.1$ \\
Particle size - silt $(4-63 \mu \mathrm{m}, \%)$ & $80.6 \pm 0.3$ \\
Particle size - sand $(63-1000 \mu \mathrm{m}, \%)$ & $6.8 \pm 0.5$ \\
Water content (\%) & $31.0 \pm 1.5$ \\
LOI (\%) & $2.4 \pm 0.1$ \\
$\mathrm{P}_{\mathrm{ICP}}\left(\mathrm{mg} \mathrm{kg}^{-1} \mathrm{DW}\right)$ & $692 \pm 11$ \\
$\mathrm{~N}\left(\mathrm{mg} \mathrm{kg}^{-1} \mathrm{DW}\right)$ & $1178 \pm 52$ \\
$\mathrm{Fe}\left(\mathrm{mg} \mathrm{g}^{-1} \mathrm{DW}\right)$ & $22 \pm 0.5$ \\
$\mathrm{Mn}\left(\mathrm{mg} \mathrm{kg}^{-1} \mathrm{DW}\right)$ & $653 \pm 5.5$ \\
$\mathrm{Al}\left(\mathrm{mg} \mathrm{g}^{-1} \mathrm{DW}\right)$ & $51 \pm 0.4$ \\
$\mathrm{Ca}\left(\mathrm{mg} \mathrm{g}^{-1} \mathrm{DW}\right)$ & $6.5 \pm 0.2$ \\
\hline
\end{tabular}

SD, standard deviation; LOI, loss on ignition; $P_{I C P}, P$ examined by ICPAES; DW, dry weight. ence was only detected between the oven-dried $(20.8 \pm 2.0$ $\mathrm{mg} \mathrm{kg}-1)$ and freeze-dried $\left(24.2 \pm 1.4 \mathrm{mg} \mathrm{kg}^{-1}\right)$ samples. No significant difference was detected for $\mathrm{P}_{\mathrm{HCl}}, \mathrm{P}_{\mathrm{Res}}$, or $\mathrm{P}_{\mathrm{Extr}}$ among the four pretreatments (Figs. 1 and 2, Tab. 3). The $\mathrm{P}_{\text {extr }} / \mathrm{P}_{\text {ICP }}$ ratio ranged from $86.1 \pm 0.9$ to $89.8 \pm 2.1 \%$ in the four pretreatments (Tab. 4).

Tab. 3. Results of one-way ANOVA for phosphorus fractions with treatment (fresh, freeze-drying, air-drying, and oven-drying) as the factor.

\begin{tabular}{lccc}
\hline P fraction & df & $\mathrm{F}$ & $\mathrm{P}$ \\
\hline $\mathrm{P}_{\mathrm{NaCl}}$ & 3 & 178 & $<0.001^{* * *}$ \\
$\mathrm{P}_{\mathrm{BD}}$ & 3 & 24.2 & $<0.001^{* * *}$ \\
$\mathrm{P}_{\mathrm{NaOH}}$ & 3 & 35.9 & $<0.001^{* * *}$ \\
$\mathrm{P}_{\text {Org }}$ & 3 & 3.52 & $0.034^{*}$ \\
$\mathrm{P}_{\mathrm{HCl}}$ & 3 & 1.96 & 0.152 \\
$\mathrm{P}_{\text {Res }}$ & 3 & 1.02 & 0.405 \\
$\mathrm{P}_{\text {Extr }}$ & 3 & 1.67 & 0.205 \\
\hline
\end{tabular}

$P_{E x t r}$ (total extracted $P$ ) is the sum of $P_{N a C b}, P_{B D}, P_{N a O H}, P_{O r g}, P_{H C l}$ and $P_{\text {Res }}{ }^{*} P<0.05,{ }^{* * *} P<0.001$.
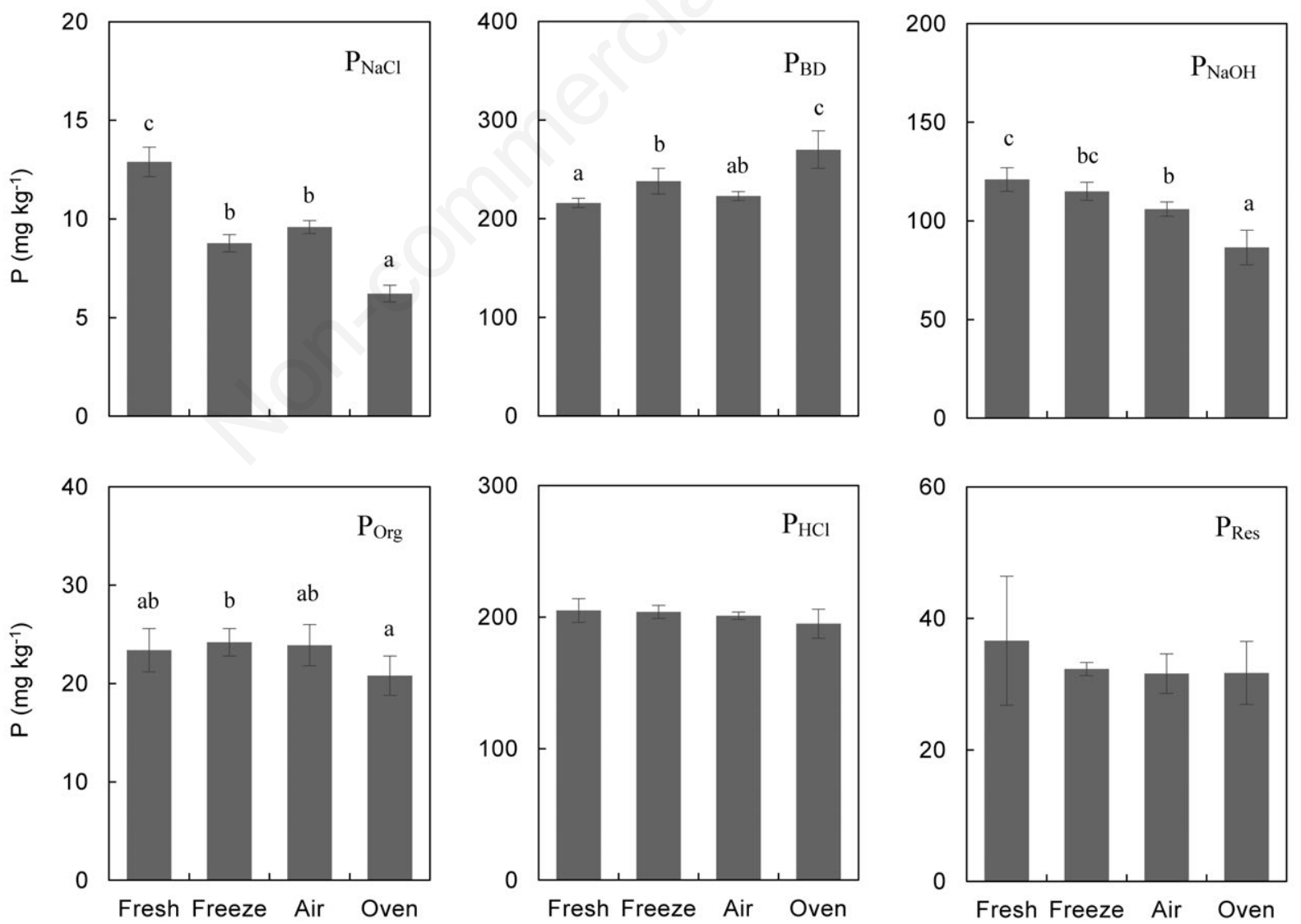

Fig. 1. Phosphorus fractions subjected to four different pretreatments. Results are expressed as mean \pm 1 standard deviation $(n=6)$ on the basis of dry weight. Different letters indicate the significant difference at the $\mathrm{P}<0.05$ level (Tukey's post-hoc test). Freeze, freeze-drying; air, air-drying; oven, oven-drying. 


\section{DISCUSSION}

As a key element for eutrophication and cyanobacterial blooms, P is concerned world widely (Schelske, 2009; Paerl et al., 2011). P deposited in sediment bed has been recognized as a P sink in the whole P cycling (Mackey and Paytan, 2009). However, deposited $\mathrm{P}$ has been verified to release from sediment to overlying water (Spears et al., 2007; Hickey and Gibbs, 2009). P release from sediment provides more nutrient to phytoplankton, which causes the algal bloom and deteriorate water quality (Søndergaard et al., 2001; Heisler et al., 2008). To overcome this problem, some costly geo-engineering have been used in lakes and reservoirs (Spears et al., 2013a). P fractionation plays an important role in making the geo-engineering decision and evaluating the effect of geo-engineering, because geo-en-

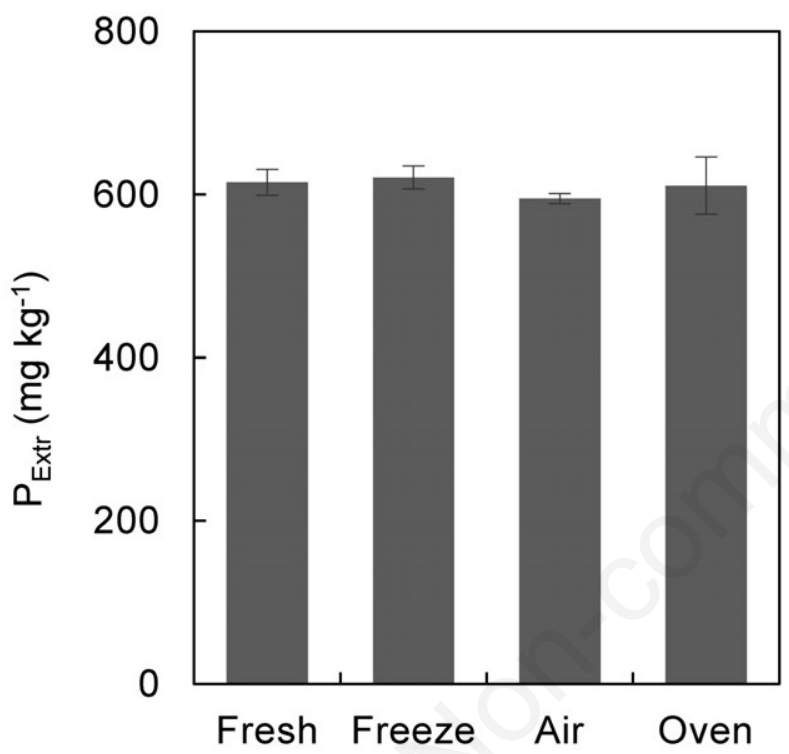

Fig. 2. $P_{\text {Extr }}$ (total extracted $P$ ) in four different pretreatments. $P_{\text {Extr }}$ is the sum of $\mathrm{P}_{\mathrm{NaCl}}, \mathrm{P}_{\mathrm{BD}}, \mathrm{P}_{\mathrm{NaOH}}, \mathrm{P}_{\mathrm{Org}}, \mathrm{P}_{\mathrm{HCl}}$, and $\mathrm{P}_{\mathrm{Res}}$. Results are expressed as mean \pm 1 standard deviation $(n=6)$ on the basis of dry weight. Freeze, freeze-drying; air, air-drying; oven, oven-drying.

Tab. 4. Percentage of $\mathrm{P}_{\text {Extr }} / \mathrm{P}_{\text {ICP }}$ in samples subjected to four different treatments $(n=6)$.

\begin{tabular}{lc}
\hline Pretreatment & $\begin{array}{c}\mathrm{P}_{\text {Extr }} / \mathrm{P}_{\text {ICP }} \\
(\mathrm{Mean} \pm \mathrm{SD})\end{array}$ \\
\hline Fresh & $88.8 \pm 2.3$ \\
Freeze-drying & $89.8 \pm 2.1$ \\
Air-drying & $86.1 \pm 0.9$ \\
Oven-drying & $88.3 \pm 5.1$ \\
\hline
\end{tabular}

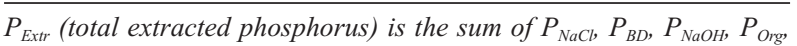
$P_{H C l}$ and $P_{R e s} ; P_{I C P}$ phosphorus in sediment examined by ICP-AES; $S D$, standard deviation. gineering is aimed to decrease the potentially releasable $\mathrm{P}$ (Meis et al., 2012). Several extraction procedure and their improved versions are available for sediment $\mathrm{P}$ fractionation (Wang et al., 2013); among them, the Psenner et al. (1988) extraction procedure and its modifications are effective in evaluating the potential P release, and is widely used in decision making and effect evaluating in geo-engineering (Meis et al., 2012). This is why we adopted the Jensen and Thamdrup (1993) procedure that is a modification version of Psenner et al., (1988).

In the extraction procedure, $\mathrm{P}_{\mathrm{NaCl}}$ represents the $\mathrm{P}$ in pore water and the $\mathrm{P}$ loosely adsorbed onto sediment particles (Jensen and Thamdrup, 1993). It is a fraction of high likelihood of P release (Meis et al., 2012). Our results showed that drying decreased this $P$ fraction (Fig. 1). In a study on peat soil, air-drying and freeze-drying also decreased P in soil solution and the labile-form P (Schlichting and Leinweber, 2002). Goedkoop and Pettersson (2000) however, have reported that freeze-drying increased the loosely adsorbed inorganic $\mathrm{P}$ of surface sediment $(0-5 \mathrm{~mm})$ by $20 \%$. Kerr et al. (2010) also found drying increased loosely adsorbed $\mathrm{P}$ with surficial sediment $(0-2 \mathrm{~cm})$ (Tab. 5). The difference in sediment characteristics used in the three studies may be responsible for the contradictory results. Goedkoop and Pettersson (2000) used surface sediment, which contained some algae cells and was rich in organic matter (87.5 $\left.\mathrm{C} \mathrm{mg} \mathrm{g}^{-1} \mathrm{DW}\right)$. During freeze-drying, cell disruption and other processes make the intracellular P more readily extractable, which is why Goedkoop and Pettersson (2000) observed an increase in the loosely adsorbed $\mathrm{P}$ content after freeze-drying. The LOI of surface sediments used by (Kerr et al., 2010 ) varied from $5.9 \%$ to $15.6 \%$. The sediment used in our experiment was from a depth of $2-5 \mathrm{~cm}$, with low organic matter (LOI, 2.4\%); therefore, little or no more intracellular P was extractable after the sample was dried. In addition, the sediment in the present study would be oxidized during pretreatment, and some free $\mathrm{P}$ in fresh sediment would be confined by physical or chemical adsorption, which would prevent it from dissolving in $\mathrm{NaCl}$ solution (as can be verified by the change in $\mathrm{P}_{\mathrm{BD}}$ ). However, the sediments used by Goedkoop and Pettersson (2000) were surface sediment. We speculate that the surface sediment should be aerobic, and aerobic sediment may be influenced weakly by oxygen during drying compared with anaerobic sediment. Thus, pretreatment is able to produce different effects on $\mathrm{P}_{\mathrm{NaCl}}$ in diverse sediments.

$\mathrm{P}_{\mathrm{BD}}$ is the redox-sensitive $\mathrm{P}$ bound to reducible $\mathrm{Fe}$ and Mn oxides (Lukkari et al., 2007a). The oxidation of ferrous iron would produce ferric oxyhydroxides, which adsorb $\mathrm{P}$ and increase $\mathrm{P}_{\mathrm{BD}}$ (Gunnars et al., 2002; Lewandowski and Hupfer, 2005). More $\mathrm{P}_{\mathrm{BD}}$ was extracted from anaerobic sediment stored in an aerobic atmosphere than from that stored in an anaerobic atmosphere (Psenner and Pucsko, 1988; 
Lukkari et al., 2007b). Drying has also been verified to increase $\mathrm{P}_{\mathrm{BD}}$ (Fabre, 1992; Kerr et al., 2010) (Tab. 5). In the present study, sediment samples contacted air during drying, and we observed that the $\mathrm{P}_{\mathrm{BD}}$ increased in dried sediment samples (Fig. 1). Oven-drying resulted in the greatest $\mathrm{P}_{\mathrm{BD}}$ because oven-drying involved the highest temperature $\left(60^{\circ} \mathrm{C}\right)$ used in any of the sample treatments. The oxidation of $\mathrm{Fe}$ and the adsorption of $\mathrm{P}$ onto ferric oxyhydroxides would increase with increasing temperature (Millero et al., 1987; Mezenner and Bensmaili, 2009).

$\mathrm{P}_{\mathrm{NaOH}}$ primarily represents $\mathrm{P}$ bound to $\mathrm{Al}$ oxides as well as some P bound to non-reducible Fe (Jensen and Thamdrup, 1993; Lukkari et al., 2007a). In a previous study, freeze-drying and verified to decrease $\mathrm{P}_{\mathrm{NaOH}}$ compared with that of fresh surface sediment (Goedkoop and Pettersson, 2000). In the present study, freeze-drying did not decrease $\mathrm{P}_{\mathrm{NaOH}}$ significantly, whereas air-drying and oven-drying significantly decreased $\mathrm{P}_{\mathrm{NaOH}}$ (Fig. 1). This result may result from air-drying and oven-drying being conducted at higher temperatures than freeze-drying. Notably, although both $\mathrm{P}_{\mathrm{BD}}$ and $\mathrm{P}_{\mathrm{NaOH}}$ are bound to metal oxides, different results were observed after the drying pretreatment: the drying pretreatment decreased $\mathrm{P}_{\mathrm{NaOH}}$ but increased $\mathrm{P}_{\mathrm{BD}}$. This difference is possibly because the dehydration of sediment particles and colloids, and the coprecipitation of solutes in pore water should have changed chemical forces and impeded the exchange of $\mathrm{P}$ forms across the solid-solution interface during pretreatments (Goedkoop and Pettersson, 2000).
Freeze-drying has been shown to decrease $\mathrm{P}_{\text {Org }}$ by $23 \%$ compared with that of fresh sediment (Goedkoop and Pettersson, 2000); drying has also been shown to reduce the concentration of organic $\mathrm{P}$ in an extract solution from peat soil (Schlichting and Leinweber, 2002). In our study, drying pretreatments were prone to decrease $\mathrm{P}_{\text {Org }}$ as well. However, the only significant difference was detected between freezedrying and oven-drying, whereas freeze-drying and fresh sediment shared similar results. The decrease observed after oven-drying may be because oven-drying facilitates the hydrolysis of organic P (Ajiboye et al., 2004). The organic matter in the sediment sample is low, and the majority of organic P in the sediment of Lake Taihu is relatively stable and not degrades into inorganic $\mathrm{P}$ in short time (Bai et al., 2009); both of these factors may be responsible for the relatively small change in $\mathrm{P}_{\text {Org }}$. In sediment with more organic matter, $\mathrm{P}_{\mathrm{Org}}$ is likely more easily influenced by pretreatment; for example, both the above-mentioned peat soil (ash content $63.5 \%$ ) and surficial sediment $\left(87.5 \mathrm{C} \mathrm{mg} \mathrm{g}^{-1} \mathrm{DW}\right)$ exhibited high organic matter contents.

$\mathrm{P}_{\mathrm{HCl}}$ mainly represents $\mathrm{P}$ bound to apatite in sediment, and it often changes when the $\mathrm{pH}$ is altered (Rydin 2000). In the present study, however, $\mathrm{P}_{\mathrm{HCl}}$ was not influenced by pretreatment. Fabre (1992) and Kerr et al., (2010) also found the consistent result. However, less $\mathrm{P}_{\mathrm{HCl}}$ was extracted when anaerobic sediment was preserved in air for 89 days compared with that extracted from fresh sediment (Lukkari et al., 2007b). Compared with the storage of 89

Tab. 5. Effects of storage, drying, and other similar process on the phosphorus fractionation results.

\begin{tabular}{|c|c|c|c|}
\hline $\begin{array}{l}\text { Sediment } \\
\text { characteristic }\end{array}$ & Pretreatment or other similar process & Effect & Reference \\
\hline Sediment core & Anaerobic storage & Keeping $\mathrm{P}_{\mathrm{BD}}$ constant & Psenner and Pucsko, 1988 \\
\hline Sediment core & Aerobic storage & Increasing $\mathrm{P}_{\mathrm{BD}}$ strongly & Psenner and Pucsko, 1988 \\
\hline Surface aerobic sediment & Natural drying & $\begin{array}{l}\text { Increasing iron bound } \mathrm{P} \text {, have no } \\
\text { effect on calcium bound } \mathrm{P}\end{array}$ & Fabre, 1992 \\
\hline Surface sediment & Natural drying (desiccation) & $\begin{array}{l}\text { Increasing iron bound } \mathrm{P} \text {, decreasing } \\
\text { calcium bound } \mathrm{P} \text {, and accelerating the } \\
\text { mineralization of acid soluble organic } \mathrm{P}\end{array}$ & De Groot and Fabre, 1993 \\
\hline Unavailable & Freezing or drying & Changing the $\mathrm{P}$ fractionation results & Golterman, 1996 \\
\hline Surficial $5 \mathrm{~mm}$ sediment & Freezing and freeze-drying & $\begin{array}{l}\text { Increasing labile } \mathrm{P} \text { and decreasing } \mathrm{P} \\
\text { extracted by } \mathrm{NaOH} \text { solution }\end{array}$ & Goedkoop and Pettersson, 2000 \\
\hline Reduced sediment & Long-term anaerobic storage & Causing minor changes on $\mathrm{P}$ fractions & Lukkari et al., 2007b \\
\hline Reduced sediment & Long-term aerobic storage & Increasing $\mathrm{P}_{\mathrm{BD}}$ strongly and decreasing $\mathrm{P}_{\mathrm{HCl}}$ & Lukkari et al., 2007b \\
\hline Aerobic sediment & Long-term anaerobic storage & Decreasing $\mathrm{P}_{\mathrm{BD}}$ and $\mathrm{P}_{\mathrm{Org}}$ & Lukkari et al., 2007b \\
\hline Aerobic sediment & Long-term aerobic storage & Decreasing $\mathrm{P}_{\mathrm{BD}}$ & Lukkari et al., 2007b \\
\hline Surficial $2 \mathrm{~cm}$ sediment & $\begin{array}{l}\text { Nature and laboratory } \\
\text { drying (desiccation) }\end{array}$ & $\begin{array}{c}\text { Increasing labile } \mathrm{P} \text { and decreasing } \mathrm{P}_{\mathrm{Org}} \text {; } \\
\text { changes of } \mathrm{P}_{\mathrm{BD}} \text { and } \mathrm{P}_{\mathrm{NaOH}} \text { depending on the } \\
\text { sediment characteristics; laboratory drying } \\
\text { has no influence on } \mathrm{P}_{\mathrm{HCl}} \text { and } \mathrm{P}_{\mathrm{Res}}\end{array}$ & Kerr et al., 2010 \\
\hline
\end{tabular}


days, laboratory drying was finished in a short time, which might prevent changes in the $\mathrm{P}_{\mathrm{HCl}}$ content in the sediment.

$\mathrm{P}_{\mathrm{Res}}$ mainly represents the refractory organic $\mathrm{P}$ and the inert inorganic P fractions (Rydin 2000). The results of the present study indicate that this $\mathrm{P}$ fraction is not influenced by pretreatment. Kerr et al. (2010) found the same result. These results are contrary to those obtained from soil $\mathrm{P}$ fractionation, where $\mathrm{P}_{\text {Res }}$ increased following pretreatment, and this increase was attributed to the increase of organic $\mathrm{P}$ in $\mathrm{P}_{\text {Res }}$ (Schlichting and Leinweber, 2002). Pretreatment did not influence $P_{\text {Extr, }}$, which means that the pretreatment only changed the $\mathrm{P}$ bonding forms in the sediment. The $\mathrm{P}_{\mathrm{HCl}}$ and $\mathrm{P}_{\mathrm{Res}}$ also exhibited similar results; we therefore speculate that pretreatment induced the transformation of phosphorus among the forms of $\mathrm{P}_{\mathrm{NaCl}}, \mathrm{P}_{\mathrm{BD}}, \mathrm{P}_{\mathrm{NaOH}}$, and $\mathrm{P}_{\mathrm{Org}}$. In addition, organic matter may play an important role in the effects of pretreatment on $\mathrm{P}$ fractionation on the basis of the previous discussion. For sediment with a high organic matter content, the results may differ. To answer this question, a study concerning the effect of pretreatment on sediment fractionation with a range of sediment types should be carried out in the future work. In addition, an inter-calibration exercise between laboratories from different countries may provide more useful information on the operation of this procedure.

In general, compared with fresh sediment, sediment pretreated by drying decreased $\mathrm{P}_{\mathrm{NaCl}}, \mathrm{P}_{\mathrm{NaOH}}$, and $\mathrm{P}_{\mathrm{Org}}$ but elevated $\mathrm{P}_{\mathrm{BD}}$. Among the three drying pretreatment methods, oven-drying resulted in the greatest change in $\mathrm{P}$ fractionation. $\mathrm{P}_{\mathrm{NaCl}}, \mathrm{P}_{\mathrm{BD}}$, and $\mathrm{P}_{\mathrm{NaOH}}$ are the mobile $\mathrm{P}$ fractions, and they play a key role in assessing the release potential of $\mathrm{P}$ in sediment. Accurate determination of these $\mathrm{P}$ fractions is the basis for investigating $\mathrm{P}$ release. In some costly geo-engineering projects designed to control internal $\mathrm{P}$ loading, this method has been used to make decision (Meis et al., 2012; Spears et al., $2013 \mathrm{~b}$ ). The uncertainty around this extraction procedure may lead to large variation in the engineer cost. Our study indicates that fresh sediment is the best choice for the precise examination of sediment $\mathrm{P}$ fractions. If pretreatment is unavoidable, freeze-drying and air-drying are recommended, whereas oven-drying is not. The results give more profound understanding in assessing $\mathrm{P}$ release potentiality by this procedure and in the operation of this fractionation method.

\section{ACKNOWLEDGMENTS}

The study was funded by the National Natural Science Foundation of China (41103033), the Fundamental Research Funds for the Central Universities (JKQ2011030), the Basic research program of Jiangsu Province (BK2011879), and the State Major Project of Water Pollution Control and Management (2012ZX07103-005). We sincerely thank Zaisheng Yan, Ming Kong, Mo Chen, and Yanli Zhou for their friendly assistances in the laboratory.

\section{REFERENCES}

Ajiboye B, Akinremi OO, Racz GJ, 2004. Laboratory characterization of phosphorus in fresh and oven-dried organic amendments. J. Environ. Qual. 33:1062-1069.

Bai X, Ding S, Fan C, Liu T, Shi D, Zhang L, 2009. Organic phosphorus species in surface sediments of a large, shallow, eutrophic lake, Lake Taihu, China. Environ. Pollut. 157: 2507-2513.

Carpenter SR, 2008. Phosphorus control is critical to mitigating eutrophication. P. Natl. Acad. Sci. USA 105:11039-11040.

Chinese EPA, 2002. [Methods for the examination of water and wastewater], $4^{\text {th }}$ ed. [Book in Chinese]. China Environmental Science Press, Beijing: 836 pp.

De Groot CJ, Fabre A, 1993. The impact of desiccation of a freshwater marsh (Garcines Nord, Camargue, France) on sediment-water-vegetation interactions. Part 3. The fractional composition and the phosphate adsorption characteristics of the sediment. Hydrobiologia 252:105-116.

Elser JJ, 2012. Phosphorus: a limiting nutrient for humanity? Curr. Opin. Biotechnol. 23:833-838.

Fabre AC, 1992. Inorganic phosphate in exposed sediments of the River Garonne. Hydrobiologia 228:37-42.

Gikuma-Njuru P, Hecky R, Guildford S, 2010. Surficial sediment phosphorus fractions along a biogeochemical gradient in Nyanza (Winam) Gulf, northeastern Lake Victoria and their possible role in phosphorus recycling and internal loading. Biogeochemistry 97:247-261.

Goedkoop W, Pettersson K, 2000. Seasonal changes in sediment phosphorus forms in relation to sedimentation and benthic bacterial biomass in Lake Erken. Hydrobiologia 431:41-50.

Golterman H, 1996. Fractionation of sediment phosphate with chelating compounds: a simplification, and comparison with other methods. Hydrobiologia 335:87-95.

Golterman HL, 2004. The chemistry of phosphate and nitrogen compounds in sediments. Kluwer Academic Publishers, Dordrecht.

Gunnars A, Blomqvist S, Johansson P, Andersson C, 2002. Formation of $\mathrm{Fe}$ (III) oxyhydroxide colloids in freshwater and brackish seawater, with incorporation of phosphate and calcium. Geochim. Cosmochim. Acta 66:745-758.

Heisler J, Glibert PM, Burkholder JM, Anderson DM, Cochlan W, Dennison WC, Dortch Q, Gobler CJ, Heil CA, Humphries E, Lewitus A, Magnien R, Marshallm HG, Sellner K, Stockwell DA, Stoecker DK, Suddleson M, 2008. Eutrophication and harmful algal blooms: a scientific consensus. Harmful Algae 8:3-13.

Hickey CW, Gibbs MM, 2009. Lake sediment phosphorus release management - decision support and risk assessment framework. N. Z. J. Mar. Freshwater Res. 43:819-856.

Jensen HS, Thamdrup B, 1993. Iron-bound phosphorus in marine sediments as measured by bicarbonate-dithionite extraction. Hydrobiologia 253:47-59.

Kerr JG, Burford M, Olley J, Udy J, 2010. The effects of drying on phosphorus sorption and speciation in subtropical river sediments. Mar. Freshwater Res. 61:928-935.

Lewandowski J, Hupfer M, 2005. Effect of macrozoobenthos 
on two-dimensional small-scale heterogeneity of pore water phosphorus concentrations in lake sediments: a laboratory study. Limnol. Oceanogr. 50:1106-1118.

Lukkari K, Hartikainen H, Leivuori M, 2007a. Fractionation of sediment phosphorus revisited: I Fractionation steps and their biogeochemical basis. Limnol. Oceanogr. Meth. 5:433-444.

Lukkari K, Leivuori M, Hartikainen H, 2007b. Fractionation of sediment phosphorus revisited: II Changes in phosphorus fractions during sampling and storing in the presence or absence of oxygen. Limnol. Oceanogr. Meth. 5:445-456.

Mackey KRM, Paytan A, 2009. Phosphorus cycle, p. 322-334. In: M. Schaechter (ed.) Encyclopedia of microbiology. $3^{\text {rd }}$ ed. Academic Press, Oxford.

Meis S, Spears BM, Maberly SC, O’Malley MB, Perkins RG, 2012. Sediment amendment with Phoslock ${ }^{\circledR}$ in Clatto Reservoir (Dundee, UK): investigating changes in sediment elemental composition and phosphorus fractionation. J. Environ. Manage. 93:185-193.

Mezenner NY, Bensmaili A, 2009. Kinetics and thermodynamic study of phosphate adsorption on iron hydroxide-eggshell waste. Chem. Eng. J. 147:87-96.

Millero FJ, Sotolongo S, Izaguirre M, 1987. The oxidation kinetics of $\mathrm{Fe}$ (II) in seawater. Geochim. Cosmochim. Acta 51:793-801.

Murphy J, Riley J, 1962. A modified single solution method for the determination of phosphate in natural waters. Anal. Chim. Acta 27:31-36.

Paerl HW, Hall NS, Calandrino ES, 2011. Controlling harmful cyanobacterial blooms in a world experiencing anthropogenic and climatic-induced change. Sci. Total Environ. 409:1739-1745.

Paytan A, McLaughlin K, 2007. The oceanic phosphorus cycle. Chem. Rev. 107:563-576.

Psenner R, Boström B, Dinka M, Pettersson K, Pucsko R, Sager M, 1988. Fractionation of phosphorus in suspended matter and sediment. Arch. Hydrobiol. Beih. Ergebn. Limnol. 30:98-103.

Psenner R, Pucsko R, 1988. Phosphorus fractionation: advantages and limits of the method for the study of sediment $P$ origins and interactions. Arch. Hydrobiol. Beih. Ergebn. Limnol. 30:43-59.

Ruban V, López-Sánchez J, Pardo P, Rauret G, Muntau H, Quevauviller $P, 1999$. Selection and evaluation of sequential extraction procedures for the determination of phosphorus forms in lake sediment. J. Environ. Monit. 1:51-56.

Ruban V, López-Sánchez JF, Pardo P, Rauret G, Muntau H, Quevauviller P, 2001. Harmonized protocol and certified reference material for the determination of extractable contents of phosphorus in freshwater sediments - A synthesis of recent works. Fresenius J. Anal. Chem. 370:224-228.

Rydin E, 2000. Potentially mobile phosphorus in Lake Erken sediment. Water Res. 34:2037-2042.

Søndergaard M, Jensen P, Jeppesen E, 2001. Retention and internal loading of phosphorus in shallow, eutrophic lakes. Scientific World J. 1:427-442.

Schelske CL, 2009. Eutrophication: focus on phosphorus. Science 324:722.

Schlichting A, Leinweber P, 2002. Effects of pretreatment on sequentially-extracted phosphorus fractions from peat soils. Commun. Soil Sci. Plant Anal. 33:1617-1627.

Sharpley A, Jarvie HP, Buda A, May L, Spears B, Kleinman P, 2013. Phosphorus legacy: Overcoming the effects of past management practices to mitigate future water quality impairment. J. Environ. Qual. 42:1308-1326.

Spears BM, Carvalho L, Paterson DM, 2007. Phosphorus partitioning in a shallow lake: implications for water quality management. Water Environ. J. 21:47-53.

Spears BM, Dudley B, Reitzel K, Rydin E, 2013a. Geo-engineering in lakes - A call for consensus. Environ. Sci. Technol. 47:3953-3954.

Spears BM, Meis S, Anderson A, Kellou M, 2013b. Comparison of phosphorus $(\mathrm{P})$ removal properties of materials proposed for the control of sediment $p$ release in UK lakes. Sci. Total Environ. 442:103-110.

Sun S, Huang S, Sun X, Wen W, 2009. Phosphorus fractions and its release in the sediments of Haihe River, China. J. Environ. Sci. 21:291-295.

Wang C, Zhang Y, Li H, Morrison RJ, 2013. Sequential extraction procedures for the determination of phosphorus forms in sediment. Limnology 14:147-157.

Zhang L, Gu X, Fan C, Shang J, Shen Q, Wang Z, Shen J, 2010. Impact of different benthic animals on phosphorus dynamics across the sediment-water interface. J. Environ. Sci. 22:1674-1682.

Zhong J, You B, Fan C, Li B, Zhang L, Ding S, 2008. Influence of sediment dredging on chemical forms and release of phosphorus. Pedosphere 18:34-44. 